Vol. 15 (2006): 252-267.

\title{
Microbial protein synthesis, digestion and lactation responses of cows to grass or grass-red clover silage diet supplemented with barley or oats
}

\author{
Aila Vanhatalo, Tomas Gäddnäs \\ Department of Animal Science, PO Box 28, FI-00014 University of Helsinki, Finland, \\ e-mail: aila.vanhatalo@helsinki.fi \\ Terttu Heikkilä \\ MTT Agrifood Research Finland, Animal Production Research, FI-31600 Jokioinen, Finland
}

\begin{abstract}
The study was conducted to evaluate effects of silage type (grass-red clover vs. pure grass) and grain supplement (oats vs. barley) on rumen fermentation, post-ruminal nutrient flows, diet digestion and milk production. Four primiparous Finnish Ayrshire cows fitted with cannulae in the rumen and duodenum were used in a $4 \times 4$ Latin square experiment with four 28 -d experimental periods and $2 \times 2$ factorial arrangements of treatments. Using red clover-containing (40\%) silage rather than pure grass silage had minor effects on rumen fermentation or diet digestion but increased non-ammonia nitrogen $(\mathrm{N})$ flow in terms of increased flows of microbial and dietary $\mathrm{N}$ entering to the small intestine. This was reflected as a reduced ruminal $\mathrm{N}$ degradability on grass-red clover diets. Furthermore, grass-red clover diets in comparison to grass silage diets increased milk lactose concentration and yields of milk, protein and lactose. Feeding oats in replacement for barley had minor effects on rumen fermentation or post-ruminal non-ammonia $\mathrm{N}$ flows but reduced digestibility of organic matter and neutral detergent fibre in the diet. Using oats rather than barley increased yields of milk and lactose but reduced milk protein concentration. Oats also increased proportions of $\mathrm{C}_{18: 0}$ and $\mathrm{C}_{18: 1}$ in milk fat and reduced those of $\mathrm{C}_{10: 0}$ to $\mathrm{C}_{16: 0}$. It is concluded that inclusion of red clover and replacement of barley with oats in grass silage based diets have beneficial effects in dairy cow production.
\end{abstract}

Key words: dairy cows, grass silage, red clover, barley, oats, rumen fermentation, microbial protein, milk fat composition

\section{Introduction}

The role of $\mathrm{N}_{2}$-fixing forage legumes has been relatively minor in conventional milk production since introduction of inexpensive nitrogen $(\mathrm{N})$ fertilisers. Currently forage legumes are primarily used in organic farming. In the long term owing to a potential to save in $\mathrm{N}$ fertilisation costs relative importance of forage legumes as a source of nutri- 
Vol. 15 (2006): 252-267.

ents for milk production may increase also in conventional farming. The most profitable forage legume available in Finnish grasslands is red clover (Trifolium pratense), which is usually grown in mixed swards and harvested as silage for the long indoor feeding period. Nutrient supply of dairy cows from forages is affected by stage of maturity, conservation method and plant species. In relation to plant species legumes deviate from grasses with respect to chemical composition and digestibility. Red clover is typically high in crude protein $(\mathrm{CP})$ and minerals while grasses are higher in contents of fibre and sugar. The rate of decline in digestibility of primary growth of red clover is only about $0.25 \%$-units $\mathrm{d}^{-1}$ compared with $0.5 \%$-units for commonly used grasses in Finland (Rinne 2000). Irrespective of the variable responses to silage dry matter (DM) intake with pure red clover silage, red clover either alone or as a part of mixed legumegrass swards has stimulated higher milk production in comparison to grasses (Thomas et al. 1985, Heikkilä et al. 1992, 1996, Randby 1992, Tuori et al. 2000, 2002, Dewhurst et al. 2003b, Bertilsson and Murphy 2003). In some of these studies, use of red clover has led to reductions in milk fat or protein concentrations and changes in milk fatty acid (FA) composition.

Barley (Hordeum vulgare) and oats (Avena sativa) grains are main cereals used for supplementation of grass silage based dairy cow rations in Finland. Oats grain is characterised with high contents of fat and fibre while barley grain is high in starch (MTT 2006). Using oats rather than barley supplementation on grass silage based dairy cow feeding has increased milk yields but reduced milk fat and protein concentrations (Heikkilä et al. 1988, Ekern et al. 2003). Furthermore, analysis of milk fat composition demonstrated that milk fat was softer as judged by the iodine value (Kankare and Antila 1984), and that the percentage of palmitic acid in milk fat decreased and that of oleic acid increased when barley was replaced with oats (Kankare and Antila 1984, Ekern et al. 2003).

Although previous data on production responses to red clover or oats diets are available, only limited data is available to explain these effects in terms of rumen fermentation or post-rumi- nal nutrient flows to the lower tract. The aim of the present study was to compare rumen fermentation and nutrient flows at duodenum, $\mathrm{N}$ flow in particular, at similar DM and $\mathrm{N}$ intakes between grassred clover and pure grass silage diets supplemented either with barley or oats. Factorial arrangement of the treatments allowed evaluation of possible interactions between the silage type and grain supplement used. Production responses including milk FA composition of cows to dietary treatments were also examined in this study. Preliminary results have been reported earlier (Vanhatalo et al. 1995).

\section{Material and methods}

All the experimental procedures with regard to the use of animals in the present study were reviewed and approved by the local Animal Care and use Committee.

\section{Experimental feeds, animals and diets}

The experimental silages were prepared from secondary growth of meadow fescue (Festuca pratensis) -timothy (Phleum pratense) and red clovercontaining meadow fescue-timothy swards at the Jokioinen experimental farm of MTT Agrifood Research Finland $\left(61^{\circ} \mathrm{N}\right)$. The leys were fertilized with 90 or $50 \mathrm{~kg} \mathrm{~N} \mathrm{ha}^{-1}$ and harvested 1 and 7 September, respectively. The previous cuts of the leys were performed 15 and 16 June, respectively. Exceptionally dry periods in June and July delayed harvesting of the secondary growth. The percentage of meadow fescue in the grass sward was $94 \%$ while percentages of red clover and meadow fescue were both $40 \%$ in red clover-containing sward. The herbage was harvested as direct cut using a flail-type forage harvester and ensiled in tower silos with a formic acid based additive $(800 \mathrm{~g}$ formic acid $\mathrm{kg}^{-1}+20 \mathrm{~g}$ orthophosphoric acid $\mathrm{kg}^{-1}$ ) applied at the rate of $5.01 \mathrm{t} \mathrm{t}^{-1}$ for grass silage and $5.61 \mathrm{t}^{-1}$ for grass-red clover silage. Barley and oats produced 


\section{AGRICULTURAL AND FOOD SCIENCE}

Vanhatalo, A. et al. Responses of cows to grass-red clover diets

at the same experimental farm were coarsely ground using a hammer mill.

Four primiparous Finnish Ayrshire cows on average $13 \pm 2.7$ weeks in milk at the start of the experiment were used in the study. The cows were equipped with a rumen cannula and a simple Tpiece cannula in the proximal duodenum. The mean live weight of cows was $529 \pm 44.4 \mathrm{~kg}$ at the beginning of the experiment, and $539 \pm 42.4 \mathrm{~kg}$ at the end of the experiment. The study was designed as a balanced $4 \times 4$ Latin square with a $2 \times 2$ factorial arrangement of dietary treatments. Cows were fed at the level of production requirements either on grass silage or grass-red clover silage $(0.60 \mathrm{~kg}$ $\mathrm{kg}^{-1}$ diet DM) supplemented either with barley or oats $\left(0.40 \mathrm{~kg} \mathrm{~kg}^{-1}\right.$ diet DM). The restricted level of feed intake of each cow was adjusted on the basis of the individually measured ad libitum silage intake during one week before the start of the experiment. Each concentrate contained $53 \mathrm{~g} \mathrm{~kg}^{-1}$ of a mineral supplementation (Nurmi-Minera, Suomen Rehu Ltd, Helsinki, Finland) containing 170 $\mathrm{g} \mathrm{Ca} \mathrm{kg}^{-1}, 81 \mathrm{~g} \mathrm{P} \mathrm{kg}^{-1}, 60 \mathrm{~g} \mathrm{Mg} \mathrm{kg}^{-1}$ and $69 \mathrm{~g} \mathrm{Na}$ $\mathrm{kg}^{-1}$. The cows had free access to water and they were fed two equal meals at 0600 and 1800 . Cows were milked at 0700 and 1700 .

\section{Experimental procedures and chemical analyses}

Each experimental period lasted for 28 days including a 12-day adaptation period. Feed intake and milk production were recorded daily throughout the experiment, and data from the last $14 \mathrm{~d}$ of each period were used for statistical analysis.

Representative samples of the experimental feeds were obtained from each experimental period and analysed for DM, ash, CP, neutral detergent fibre (NDF), acid detergent fibre (ADF) and lignin, and as for silage samples also for $\mathrm{pH}$, water soluble carbohydrates (WSC), ammonia N and soluble $\mathrm{N}$, lactic acid and volatile fatty acids (VFA) as described before (Vanhatalo et al. 1992). Milk samples for determination of milk constituents were taken on four consecutive milkings on days 18-20 and for sensory analyses on two consecutive milkings on days 26-27 of each period. Milk samples were analysed for fat, protein and lactose by an infra-red milk analyser (Milkoscan; Foss Electric, Hillerød, Denmark) and for milk urea and FA composition as described before (Huhtanen and Heikkilä 1996). Evaluation of the milk flavour by five experienced assessors of MTT Food Research was performed on fresh samples on a scale from 0 to 5 , the lowest value representing milk unfit for human consumption and the highest value representing milk of excellent quality.

To assess rumen fermentation, rumen fluid was sampled before the morning feeding and 1, 2, 3, 4, 6, 8 and $10 \mathrm{~h}$ thereafter on $\mathrm{d} 21$, and analysed for $\mathrm{pH}$, ammonia and VFA (Vanhatalo et al. 1992). The flow of nutrients to the small intestine was determined according to the graphic alternative (McAllan and Smith 1983) of the double-marker method (Faichney 1975). Chromium-mordanted straw and LiCo-EDTA were prepared as described by Uden et al. (1980) and used as markers for the solid and liquid phase of digesta, respectively. The overall digestibility of the diets was determined using $\mathrm{TiO}_{2}$ as a marker. Chromium-mordanted straw $\left(15 \mathrm{~g} \mathrm{~d}^{-1}\right)$ and $\mathrm{TiO}_{2}\left(14 \mathrm{~g} \mathrm{~d}^{-1}\right)$ were administered into the rumen in two equal portions at feeding times, and LiCo-EDTA $\left(5 \mathrm{~g} \mathrm{~d}^{-1}\right)$ was infused continuously into the rumen from day 8 onwards on each period. Duodenal digesta spot samples $(130 \mathrm{ml})$ were collected 4 times daily at 3 hour intervals between the morning and evening feedings on 3 consecutive days (18-20) to be pooled to cover the whole $12 \mathrm{~h}$ feeding period. Faecal grab samples were taken twice a day at feeding times during 5 days of each experimental period to be pooled to form one sample per each period. The chemical composition of digesta and faecal samples as well as markers used were analysed as described before (Vanhatalo et al. 1992) except for $\mathrm{TiO}_{2}$ in faecal samples, which was analysed according to Brandt and Allam (1987). Calculation of duodenal flow of nutrients was based on the amounts of $\mathrm{Co}$ and $\mathrm{Cr}$ excreted in the faeces. The flow of microbial $\mathrm{N}$ at the duodenum was estimated using purine bases of nucleic acids as a marker as described before (Vanhatalo et al. 1992). The contents of the purine bas- 
Vol. 15 (2006): 252-267.

es in the microbial mass were analysed from duodenal samples collected on d 21 immediately before morning feeding and 4 and 8 hours thereafter. Differential centrifugation of the bacterial samples is described in detail elsewhere (Ahvenjärvi et al. 1999).

\section{Statistical analyses}

Data were analysed by the standard analysis of variance appropriate for Latin square: cow (df 3), period (df 3), treatment (df 3) and the residual effects (df 6) were the sources of variation. Rumen fluid data were subjected to a split-plot analysis of variance for repeated measurements (Snedecor and Cochran 1967). For treatment comparisons the sums of squares for experimental diets were further divided into single degree of freedom com- parisons to study effects of silage type (grass vs. grass-red clover silages) and grain supplement (barley vs. oats) and their interaction (silage type $x$ grain supplement).
The chemical composition of experimental feeds and fermentation quality of silages are given in Table 1. The DM and CP concentrations of the experimental silages were similar but grass-red clover silage had lower concentrations of NDF and $\mathrm{ADF}$ and higher concentrations of minerals [calcium $(\mathrm{Ca})$, magnesium $(\mathrm{Mg})]$ as well as NDF-N as compared with grass silages. Both of the silages were restrictively fermented as indicated with low

Table 1. Chemical composition of experimental feeds and fermentation quality of silages $\left(\mathrm{g} \mathrm{kg}^{-1} \mathrm{dry}\right.$ matter).

\begin{tabular}{|c|c|c|c|c|}
\hline Feed & Grass silage & $\begin{array}{c}\text { Grass-red } \\
\text { clover silage }^{1}\end{array}$ & Barley & Oats \\
\hline $\mathrm{pH}$ & 3.9 & 4.2 & & \\
\hline Dry matter, $\mathrm{g} \mathrm{kg}^{-1}$ & 244 & 240 & 899 & 889 \\
\hline Ash & 90 & 89 & 25 & 35 \\
\hline Crude protein & 160 & 159 & 148 & 135 \\
\hline Ether extracts & 48 & 50 & 24 & 54 \\
\hline Neutral detergent fibre (NDF) & 513 & 483 & 227 & 282 \\
\hline NDF-N, $\mathrm{g} \mathrm{kg}^{-1} \mathrm{~N}$ & 245 & 307 & 163 & 138 \\
\hline Acid detergent fibre & 292 & 282 & 57 & 119 \\
\hline Lignin & 36 & 43 & 10 & 30 \\
\hline Calcium & 4.7 & 7.1 & & \\
\hline Magnesium & 1.9 & 2.2 & & \\
\hline Phosphorus & 3.3 & 3.0 & & \\
\hline Water soluble carbohydrates & 59 & 94 & & \\
\hline Lactic acid & 34 & 16 & & \\
\hline Acetic acid & 19 & 15 & & \\
\hline Total volatile fatty acids ${ }^{2}$ & 66 & 47 & & \\
\hline Ammonia $\mathrm{N}, \mathrm{g} \mathrm{kg}^{-1} \mathrm{~N}$ & 41 & 32 & & \\
\hline Soluble $\mathrm{N}, \mathrm{g} \mathrm{kg}^{-1} \mathrm{~N}$ & 585 & 439 & & \\
\hline
\end{tabular}

${ }^{1}$ The percentage of red clover in the silage was $40 \%$.

${ }^{2}$ Silages did not contain any butyric or propionic acid. 
Vanhatalo, A. et al. Responses of cows to grass-red clover diets

concentration of fermentation acids and low proportions of ammonia $\mathrm{N}$ and soluble $\mathrm{N}$ in silage total N. However, red clover-containing silage had a higher content of WSC and lower contents of ammonia $\mathrm{N}$ and soluble $\mathrm{N}$ in total $\mathrm{N}$ than grass silage. Barley had higher $\mathrm{CP}$ and NDF-N concentrations but lower NDF and ADF concentrations than oats.

Because of restricted feeding, intakes of experimental silages and concentrates were fairly similar among all diets (Table 2). The small difference in silage DM intake originated from small amount of silage residues observed for grass silage diets. As the diurnal variation in rumen fermentation was consistent for most of the parameters measured rumen fermentation data are presented as means over the sampling times in Table 3. Significant interaction $(\mathrm{P}<0.001)$ between the sampling time and experimental diet was found for rumen $\mathrm{pH}$ and VFA concentrations owing to the lower $\mathrm{pH}$ and higher VFA concentrations during the latter part of the feeding interval ( 4 to $10 \mathrm{~h}$ after morning feeding) obtained for grass-red clover rather than grass silage diets (Fig. 1). Similarly,
Table 2. Intake of experimental feeds ( $k g$ dry matter $\left.\mathrm{d}^{-1}\right)$ by cows.

\begin{tabular}{lcrlcr}
\hline & \multicolumn{2}{c}{ Grass silage } & & \multicolumn{2}{c}{$\begin{array}{c}\text { Grass-red clover } \\
\text { silage }^{1}\end{array}$} \\
\cline { 2 - 3 } \cline { 5 - 6 } \cline { 5 - 6 } & Barley & Oats & & Barley & Oats \\
\hline Silage & 8.6 & 8.4 & & 8.9 & 8.9 \\
Concentrate & 5.6 & 5.6 & & 5.7 & 5.7 \\
Total & 5.6 & 14.0 & & 14.6 & 14.6 \\
\hline
\end{tabular}

${ }^{1}$ The percentage of red clover in the silage was $40 \%$.

${ }^{2}$ Concentrate included a commercial mineral supplement.

significant interaction $(\mathrm{P}<0.05)$ was found for concentration of rumen ammonia due to the peak values obtained earlier for grass-red clover diets than for grass diets $(2$ vs. $3 \mathrm{~h}$ after the morning feeding). On average, rumen $\mathrm{pH}$ was lower $(\mathrm{P}<$ $0.05)$ and total VFA concentrations higher $(\mathrm{P}<$ 0.01 ) for grass-red clover diets as compared with pure grass silage diets while no difference $(\mathrm{P}>$ 0.10 ) was found between the silage diets in rumen ammonia $\mathrm{N}$ concentration. Silage type did not af-

Table 3. Effects of silage type (grass vs. grass-red clover) and grain supplement (barley vs. oats) on rumen fermentation characteristics.

\begin{tabular}{|c|c|c|c|c|c|c|c|}
\hline & \multicolumn{2}{|c|}{ Grass silage } & \multicolumn{2}{|c|}{ Grass-red clover silage $^{1}$} & \multirow[b]{2}{*}{$\mathrm{SEM}^{2}$} & \multicolumn{2}{|c|}{ Statistical significance $^{3}$} \\
\hline & Barley & Oats & Barley & Oats & & Silage & Grain \\
\hline $\mathrm{pH}$ & 6.19 & 6.29 & 6.05 & 6.09 & 0.057 & $*$ & NS \\
\hline $\mathrm{NH}_{3}-\mathrm{N}, \mathrm{mmol} \mathrm{l}^{-1}$ & 11.06 & 9.80 & 9.98 & 8.72 & 0.743 & NS & NS \\
\hline Total VFA ${ }^{4}, \mathrm{mmol}^{-1}$ & 118 & 110 & 126 & 121 & 1.85 & $* *$ & $*$ \\
\hline \multicolumn{8}{|c|}{ Molar proportions of $\mathrm{VFA}^{4}, \mathrm{mmol} \mathrm{mol}^{-1}$} \\
\hline Acetate $(\mathrm{A})$ & 688 & 693 & 682 & 696 & 4.8 & NS & NS \\
\hline Propionate $(\mathrm{P})$ & 167 & 168 & 172 & 166 & 4.6 & NS & NS \\
\hline Butyrate (B) & 134 & 127 & 137 & 130 & 2.3 & NS & $*$ \\
\hline Valerate & 13.7 & 11.1 & 13.8 & 10.4 & 0.62 & NS & $* * *$ \\
\hline Isovalerate & 10.8 & 11.6 & 9.0 & 8.4 & 0.40 & $* *$ & NS \\
\hline$(\mathrm{A}+\mathrm{B}) / \mathrm{P}$ & 5.01 & 4.94 & 4.91 & 5.05 & 0.155 & NS & NS \\
\hline $\mathrm{P} / \mathrm{B}$ & 1.25 & 1.33 & 1.26 & 1.29 & 0.041 & NS & NS \\
\hline
\end{tabular}

${ }^{1}$ The percentage of red clover in the silage was $40 \%$.

${ }^{2}$ Standard error of the mean.

${ }^{3} \mathrm{NS}$, not significant; o, $\mathrm{P} \leq 0.10 ; *, \mathrm{P} \leq 0.05 ; * *, \mathrm{P} \leq 0.01 ; * * *, \mathrm{P} \leq 0.001$. No significant interactions $(\mathrm{P}>0.10)$ between silage type and grain supplement were detected in any of the parameters measured.

${ }^{4}$ Volatile fatty acids. 
Vol. 15 (2006): 252-267.

$\mathrm{pH}$

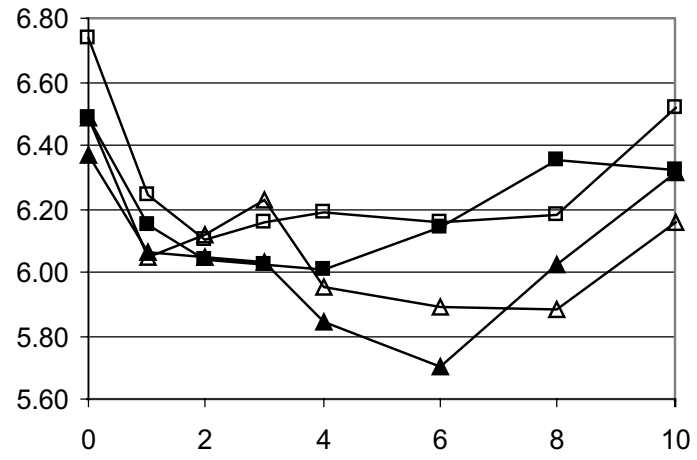

Ammonia,

$\mathrm{mmol}^{-1}$

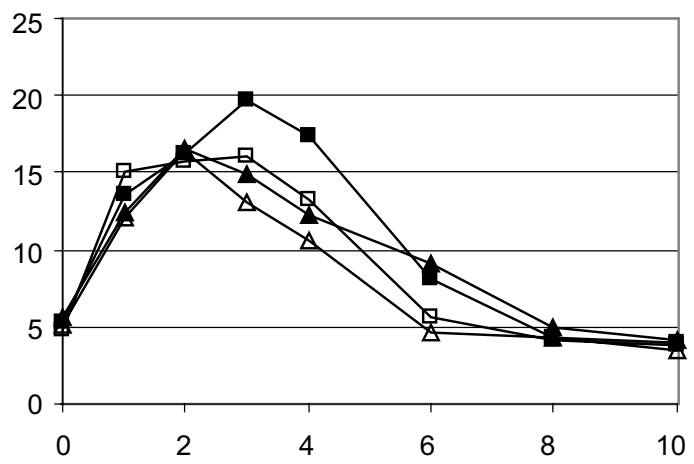

Volatile fatty

acids, $\mathrm{mmol} \mathrm{I}^{-1}$

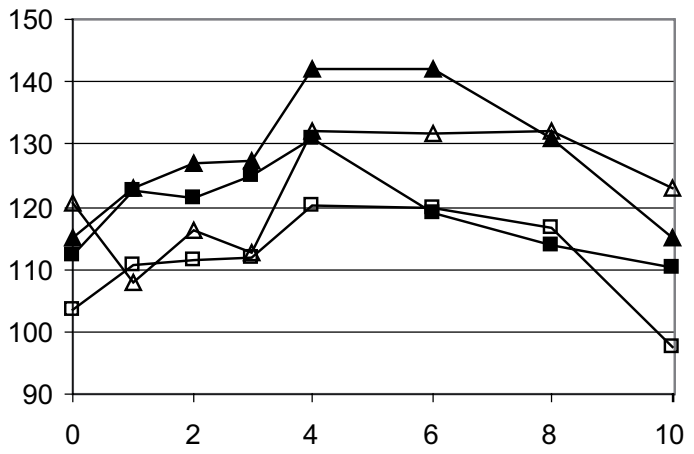

Time after morning feeding, $\mathrm{h}$

Fig. 1. Effects of dietary treatments $(\mathbf{\square}$, grass silage + barley; $\square$, grass silage + oats; $\boldsymbol{\Delta}$, grass-red clover silage + barley; $\Delta$, grass-red clover silage + oats) on diurnal variations in rumen $\mathrm{pH}$, ammonia and volatile fatty acids concentrations. fect $(\mathrm{P}>0.10)$ molar proportions of acetate, propionate or butyrate but proportion of isovalerate was higher $(\mathrm{P}<0.01)$ for grass silage than grass-red clover silage diets. In relation to concentrate type total VFA concentration and molar proportions of butyrate and valerate were higher $(\mathrm{P}<0.05)$ for barley than for oats diets.

No significant interactions $(\mathrm{P}>0.10)$ between silage type and grain supplement in organic matter $(\mathrm{OM})$ or NDF digestion (Table 4) or any other parameter measured (Tables 3-6) were detected in this study. Intakes and amounts of OM entering to the small intestine were higher $(\mathrm{P} \leq 0.01)$ for grassred clover than for grass silage diets resulting in a lower $(\mathrm{P} \leq 0.10)$ apparent or true OM digestibility in the rumen with grass-red clover diets. However, digestibility of $\mathrm{OM}$ in the total tract was unchanged $(P>0.10)$ between the silage types. There were no differences in the OM intake between the barley and oats diets $(\mathrm{P}>0.01)$, but amount of OM entering to the lower tract tended to be higher $(\mathrm{P}<$ 0.10 ), and apparent total digestibility of OM was lower $(\mathrm{P}<0.01)$ for oats than barley diets. Intake and digestibility parameters of NDF in the rumen and total tract were similar $(\mathrm{P}>0.10)$ for silage diets while intake of NDF and amount of NDF entering to the lower tract were higher $(\mathrm{P} \leq 0.05)$ for oats than barley diets. Consequently, digestibility of NDF in the rumen and in the total tract was lower for oats than barley diets $(\mathrm{P} \leq 0.05)$.

The small difference in silage DM intake observed between the silages was reflected as a slightly higher $(\mathrm{P}<0.10) \mathrm{N}$ intake with grass-red clover rather than grass silage diets (Table 5). Except for ammonia $\mathrm{N}$, the flows of the nitrogenous fractions such as microbial and feed $\mathrm{N}$ entering to the small intestine were higher $(\mathrm{P} \leq 0.05)$ for grassred clover diets than for grass silage diets. This led to a lower $(\mathrm{P}<0.05)$ degradability of feed $\mathrm{N}$ in the rumen of grass-red clover diets as compared with grass silage diets. However, apparent digestibility of $\mathrm{N}$ in the total tract was unchanged $(\mathrm{P}>0.10)$ between the silage diets. Efficiency of microbial protein synthesis expressed per kg apparently or truly digested $\mathrm{OM}$ in the rumen was higher $(\mathrm{P}<$ $0.05)$ for grass-red clover diets than for grass silage diets but unchanged if expressed per $\mathrm{kg}$ of 
Vanhatalo, A. et al. Responses of cows to grass-red clover diets

Table 4. Effects of silage type (grass vs. grass-red clover) and grain supplement (barley vs. oats) on digestion of organic matter and neutral detergent fibre.

\begin{tabular}{|c|c|c|c|c|c|c|c|}
\hline & \multicolumn{2}{|c|}{ Grass silage } & \multicolumn{2}{|c|}{$\begin{array}{l}\text { Grass-red clover } \\
\text { silage }^{1}\end{array}$} & \multirow[b]{2}{*}{ SEM $^{2}$} & \multicolumn{2}{|c|}{$\begin{array}{l}\text { Statistical } \\
\text { significance }^{3}\end{array}$} \\
\hline & Barley & Oats & Barley & Oats & & Silage & Grain \\
\hline \multicolumn{8}{|l|}{ Organic matter, $\mathrm{g} \mathrm{d}^{-1}$} \\
\hline In feed & 13379 & 13241 & 13687 & 13655 & 52.5 & $* * *$ & NS \\
\hline At duodenum & 6376 & 6582 & 6856 & 7480 & 176.8 & ** & o \\
\hline In faeces & 3795 & 4005 & 3791 & 4211 & 82.4 & NS & ** \\
\hline Apparent total digestibility & 0.717 & 0.697 & 0.723 & 0.691 & 0.0056 & NS & ** \\
\hline Apparent ruminal digestibility & 0.524 & 0.501 & 0.501 & 0.454 & 0.0119 & $*$ & $*$ \\
\hline $\begin{array}{l}\text { Apparent disappearance before small } \\
\text { intestine }\end{array}$ & 0.730 & 0.719 & 0.692 & 0.656 & 0.0155 & * & NS \\
\hline True ruminal digestibility & 0.686 & 0.661 & 0.665 & 0.632 & 0.0118 & o & $*$ \\
\hline True disappearance before small intestine & 0.957 & 0.949 & 0.919 & 0.914 & 0.0145 & $*$ & NS \\
\hline \multicolumn{8}{|l|}{ Neutral detergent fibre, $\mathrm{g} \mathrm{d}^{-1}$} \\
\hline In feed & 5671 & 5940 & 5575 & 5912 & 40.0 & NS & $* * *$ \\
\hline At duodenum & 2186 & 2880 & 2120 & 3373 & 295.4 & NS & $*$ \\
\hline In faeces & 2290 & 2628 & 2181 & 2704 & 51.6 & NS & $* * *$ \\
\hline Total digestibility & 0.596 & 0.557 & 0.610 & 0.542 & 0.0085 & NS & **** \\
\hline Ruminal digestibility & 0.615 & 0.514 & 0.624 & 0.431 & 0.0499 & NS & $*$ \\
\hline Disappearance before small intestine & 1.033 & 0.922 & 1.022 & 0.795 & 0.0834 & NS & o \\
\hline
\end{tabular}

${ }^{1}$ The percentage of red clover in the silage was $40 \%$.

${ }^{2}$ Standard error of the mean.

${ }^{3} \mathrm{NS}$, not significant; o, $\mathrm{P} \leq 0.10 ; *, \mathrm{P} \leq 0.05 ; * *, \mathrm{P} \leq 0.01 ; * * *, \mathrm{P} \leq 0.001$. No significant interactions $(\mathrm{P}>0.10)$ between silage type and grain supplement were detected in any of the parameters measured.

digestible carbohydrates in the total tract. Intake of $\mathrm{N}$ was slightly higher $(\mathrm{P}<0.05)$ for barley than oats diets but no significant differences $(\mathrm{P}>0.10)$ in the flow of nitrogenous fractions entering to the small intestine were found between the concentrate diets. Excretion of $\mathrm{N}$ in the faeces was higher $(\mathrm{P}<0.05)$ for barley than oats diets, and efficiency of microbial protein synthesis expressed per $\mathrm{kg}$ of digestible carbohydrates was higher $(\mathrm{P}<0.05)$ for oats than barley diets.

Both milk yield and energy corrected milk (ECM) yield as well as protein and lactose yields were higher $(\mathrm{P} \leq 0.01)$ for grass-red clover diets than for grass silage diets (Table 6). Silage type did not affect $(\mathrm{P}>0.10)$ milk fat, protein and urea concentrations. Lactose concentration was, however, higher $(\mathrm{P}<0.01)$ for grass-red clover diets as compared with grass silage diets. Proportions of $\mathrm{C}_{10: 0}$ to $\mathrm{C}_{14: 0}$ and $\mathrm{C}_{18: 3}$ in milk fat were higher $(\mathrm{P}<0.05)$ for grass-red clover diets as compared with grass silage diets. Milk, ECM and lactose yields were higher $(\mathrm{P} \leq 0.05)$ and milk protein concentration lower $(\mathrm{P}<0.01)$ for oats than barley diets. Proportions of $\mathrm{C}_{10: 0}$ to $\mathrm{C}_{16: 0}$ in milk fat were lower $(\mathrm{P} \leq$ 0.01) and proportions of $\mathrm{C}_{18: 0}, \mathrm{C}_{18: 1}$ and unsaturated FA in total milk fat were higher $(\mathrm{P} \leq 0.001)$ for oats than for barley diets. Organoleptic quality of milk was considered good on all experimental diets. However, estimates given to the milk samples originating from grass-red clover diets were slightly lower $(\mathrm{P}<0.10)$ than those given to milk samples from grass silage diets. 
Vol. 15 (2006): 252-267.

Table 5. Effects of silage type (grass vs. grass-red clover) and grain supplement (barley vs. oats) on nitrogen digestion.

\begin{tabular}{|c|c|c|c|c|c|c|c|}
\hline & \multicolumn{2}{|c|}{ Grass silage } & \multicolumn{2}{|c|}{$\begin{array}{c}\text { Grass-red clover } \\
\text { silage }^{1}\end{array}$} & \multirow[b]{2}{*}{ SEM $^{2}$} & \multicolumn{2}{|c|}{$\begin{array}{c}\text { Statistical } \\
\text { significance }^{3}\end{array}$} \\
\hline & Barley & Oats & Barley & Oats & & Silage & Grain \\
\hline Nitrogen $(\mathrm{N})$ in feed, $\mathrm{g} \mathrm{d}^{-1}$ & 354 & 341 & 361 & 351 & 3.6 & o & $*$ \\
\hline \multicolumn{8}{|l|}{ At duodenum, $\mathrm{g} \mathrm{d}^{-1}$} \\
\hline Total N & 327 & 331 & 364 & 388 & 11.8 & $* *$ & NS \\
\hline Ammonia $\mathrm{N}$ & 11.0 & 12.5 & 10.6 & 12.1 & 0.96 & NS & NS \\
\hline Non-ammonia $\mathrm{N}$ & 316 & 318 & 353 & 376 & 11.2 & $* *$ & NS \\
\hline Microbial N & 189 & 183 & 195 & 212 & 6.6 & * & NS \\
\hline Feed $N^{4}$ & 95 & 103 & 126 & 131 & 9.2 & * & NS \\
\hline In faeces, $\mathrm{g} \mathrm{d}^{-1}$ & 120 & 107 & 123 & 119 & 3.1 & o & $*$ \\
\hline Degradability of feed $\mathrm{N}$ in the rumen & 0.731 & 0.697 & 0.652 & 0.629 & 0.0251 & $*$ & NS \\
\hline Apparent total digestibility of $\mathrm{N}$ & 0.661 & 0.685 & 0.659 & 0.662 & 0.0080 & NS & NS \\
\hline Non-ammonia $\mathrm{N}$ at duodenum $\mathrm{N}^{-1}$ intake & 0.893 & 0.937 & 0.978 & 1.066 & 0.0282 & $* *$ & o \\
\hline \multicolumn{8}{|l|}{ Microbial N } \\
\hline $\mathrm{g} \mathrm{kg}^{-1} \mathrm{OMADR}^{5}$ & 27.4 & 28.0 & 28.8 & 34.3 & 1.31 & $*$ & o \\
\hline $\mathrm{g} \mathrm{kg}^{-1} \mathrm{OMTDR}^{6}$ & 20.7 & 21.0 & 21.6 & 24.5 & 0.71 & $*$ & o \\
\hline $\mathrm{g} \mathrm{kg}^{-1} \mathrm{DCHO}^{7}$ & 24.3 & 25.4 & 24.3 & 28.5 & 0.83 & NS & $*$ \\
\hline
\end{tabular}

${ }^{1}$ The percentage of red clover in the silage was $40 \%$.

${ }^{2}$ Standard error of the mean.

${ }^{3} \mathrm{NS}$, not significant; o, $\mathrm{P} \leq 0.10 ; *, \mathrm{P} \leq 0.05 ; * *, \mathrm{P} \leq 0.01$. No significant interactions $(\mathrm{P}>0.10)$ between silage type and grain supplement were detected in any of the parameters measured.

${ }^{4}$ Calculated assuming endogenous non-ammonia N flow to the small intestine according to Hart \& Leibholz (1990).

${ }^{5}$ Organic matter apparently digested in the rumen.

${ }^{6}$ Organic matter truly digested in the rumen.

\section{Discussion}

\section{Silage composition}

Both experimental silages were restrictively fermented in silo and of good fermentation quality as indicated by the low concentrations of fermentation acids and ammonia $\mathrm{N}$ as well as absence of butyric acid, all typical characteristics of silages ensiled with a high application rate of formic acid based additive (Jaakkola et al. 2006). The higher residual WSC content of grass-red clover than pure grass silage may be associated with the later harvest time of grass-red clover sward in autumn. The lower proportion of ammonia $\mathrm{N}$ and especially soluble $\mathrm{N}$ in silage $\mathrm{N}$ for grass-red clover silage rather than grass silage has often been shown when using a formic acid based additive (Thomas et al. 1985, Heikkilä et al. 1992, 1996, Tuori et al. 2002) and may reflect the loss of proteolytic activity due to the action of polyphenol oxidase system present in red clover (Jones et al. 1995, Sullivan and Hatfield 2006). The proportion of red clover in the red clover-containing silage was $40 \%$ according to the botanical determination corresponding well with the higher $\mathrm{Ca}$ and $\mathrm{Mg}$ concentrations determined for grass-red clover silage than for grass silage.

\section{Rumen fermentation and diet digestion}

Grass-red clover vs. grass

Higher rumen VFA concentration and lower $\mathrm{pH}$ as well as lack of differences in molar proportions of VFA with grass-red clover diets in comparison to 
Vanhatalo, A. et al. Responses of cows to grass-red clover diets

Table 6. Effects of silage type (grass vs. grass-red clover) and grain supplement (barley vs. oats) on milk yield and milk composition.

\begin{tabular}{|c|c|c|c|c|c|c|c|}
\hline & \multicolumn{2}{|c|}{ Grass silage } & \multicolumn{2}{|c|}{$\begin{array}{l}\text { Grass-red clover } \\
\text { silage }^{1}\end{array}$} & \multirow[b]{2}{*}{$\mathrm{SEM}^{2}$} & \multicolumn{2}{|c|}{$\begin{array}{c}\text { Statistical } \\
\text { significance }^{3}\end{array}$} \\
\hline & Barley & Oats & Barley & Oats & & Silage & Grain \\
\hline \multicolumn{8}{|l|}{ Yield, $\mathrm{kg} \mathrm{d}^{-1}$} \\
\hline Milk & 16.8 & 17.5 & 17.6 & 19.1 & 0.21 & ** & $* *$ \\
\hline Energy corrected milk & 18.3 & 18.6 & 18.9 & 20.2 & 0.30 & ** & * \\
\hline Fat & 0.769 & 0.770 & 0.774 & 0.840 & 0.018 & o & NS \\
\hline Protein & 0.568 & 0.574 & 0.599 & 0.612 & 0.008 & ** & NS \\
\hline Lactose & 0.837 & 0.879 & 0.893 & 0.974 & 0.013 & ** & ** \\
\hline \multicolumn{8}{|l|}{ Composition, $\mathrm{g} \mathrm{kg}^{-1}$} \\
\hline Fat & 46.6 & 44.3 & 44.5 & 44.4 & 0.68 & NS & NS \\
\hline Protein & 34.1 & 32.9 & 34.1 & 32.3 & 0.32 & NS & $* *$ \\
\hline Lactose & 49.9 & 50.2 & 50.6 & 50.9 & 0.16 & $* *$ & NS \\
\hline Urea, $\mathrm{mg} 100^{-1} \mathrm{ml}$ & 23.2 & 25.9 & 23.1 & 24.6 & 1.29 & NS & NS \\
\hline \multicolumn{8}{|c|}{ Fatty acid (FA) composition, $\mathrm{g} 100^{-1} \mathrm{~g}$ total FA } \\
\hline $\mathrm{C}_{4: 0}$ & 5.9 & 5.9 & 5.9 & 6.3 & 0.18 & NS & NS \\
\hline $\mathrm{C}_{6: 0}$ & 2.9 & 2.6 & 3.0 & 2.9 & 0.10 & o & o \\
\hline $\mathrm{C}_{8: 0}$ & 1.4 & 1.1 & 1.5 & 1.2 & 0.17 & NS & NS \\
\hline $\mathrm{C}_{10: 0}$ & 3.3 & 2.7 & 3.6 & 2.9 & 0.10 & $*$ & $* *$ \\
\hline $\mathrm{C}_{12: 0}$ & 3.6 & 2.8 & 3.9 & 3.0 & 0.09 & $*$ & $* * *$ \\
\hline $\mathrm{C}_{14: 0}$ & 13.1 & 11.4 & 13.5 & 12.0 & 0.14 & $*$ & $* * *$ \\
\hline $\mathrm{C}_{14: 1}$ & 1.0 & 1.1 & 1.2 & 1.1 & 0.05 & NS & NS \\
\hline $\mathrm{C}_{16: 0}$ & 34.4 & 29.0 & 34.3 & 29.2 & 0.49 & NS & $* * *$ \\
\hline $\mathrm{C}_{16: 1}$ & 2.4 & 2.7 & 2.1 & 2.6 & 0.19 & NS & o \\
\hline $\mathrm{C}_{18: 0}$ & 13.7 & 16.6 & 13.2 & 15.8 & 0.41 & NS & $* * *$ \\
\hline $\mathrm{C}_{18: 1}$ & 15.8 & 21.9 & 15.1 & 20.3 & 0.74 & NS & $* * *$ \\
\hline $\mathrm{C}_{18: 2}$ & 1.63 & 1.65 & 1.85 & 1.80 & 0.157 & NS & NS \\
\hline $\mathrm{C}_{18: 3}$ & 0.85 & 0.55 & 0.98 & 0.93 & 0.109 & o & NS \\
\hline Unsaturated FA & 21.8 & 28.0 & 21.2 & 26.8 & 0.74 & NS & $* * *$ \\
\hline Iodine value & 22.5 & 27.2 & 23.2 & 27.4 & 0.71 & NS & $* * *$ \\
\hline Organoleptic quality & 4.00 & 4.15 & 3.70 & 3.93 & 0.116 & o & NS \\
\hline
\end{tabular}

${ }^{1}$ The percentage of red clover in the silage was $40 \%$.

${ }^{2}$ Standard error of the mean.

${ }^{3} \mathrm{NS}$, not significant; o, $\mathrm{P} \leq 0.10, *, \mathrm{P} \leq 0.05 ; * *, \mathrm{P} \leq 0.01 ; * * *, \mathrm{P} \leq 0.001$. No significant interactions $(\mathrm{P}>0.10)$ between silage type and grain supplement were detected in any of the parameters measured.

pure grass silage diets are consistent with previous findings (Dewhurst et al. 2003a, Bertilsson and Murphy 2003). Red clover herbage in early-bloom may contain reserve polysaccharides in the form of starch nearly 8\% in DM (McDonald et al. 1991), and has possibly contributed to higher rumen VFA with grass-red clover silage. In our recent study (Kuoppala et al. 2005) it was also found that rate and extent of digestion of potentially digestible NDF was higher with red clover than with grass silage diets. The average rumen $\mathrm{pH}$ values of both silage diets were at or above the $\mathrm{pH} 6.0$ to $6.1 \mathrm{sug}$ - 
Vol. 15 (2006): 252-267.

gested critical to the inhibition of cellulolysis as measured with sheep (Mould and Ørskov 1983). Rumen $\mathrm{pH}$ of cows fed grass-red clover diets reduced, however, clearly below this threshold for many hours during the feeding interval (Fig. 1). Despite the period of depressed rumen $\mathrm{pH}$ fibre digestibility of grass-red clover diets was not impaired in comparison to grass silage diets. For most of the time during the feeding interval rumen ammonia $\mathrm{N}$ concentrations were much higher than 5 mmol $\mathrm{l}^{-1}$ (Fig. 1), which is shown to result in increased $\mathrm{N}$ losses from the rumen on grass silage based diets (Schwab et al. 2005). On the other hand, a minimum rumen ammonia concentration was not lower than $3.4 \mathrm{mmol} \mathrm{l}^{-1}$ suggesting that most recommendations for minimal ammonia concentration for bacterial needs as reviewed by Schwab et al. (2005) were exceeded during a $12 \mathrm{~h}$ feeding interval. Numerically lower average rumen ammonia concentrations and lower proportions of isovalerate in VFA for grass-red clover than grass silage diets support lower protein degradability for grass-red clover silage diets as will be discussed later.

\section{Oats vs. barley}

Changes in rumen fermentation pattern owing to replacement of barley with oats were relatively small and fermentation pattern with a small proportion of propionate typical for cows given grass silage based diets (Huhtanen 1998). Studies directly comparing oats and barley in terms of rumen fermentation in cattle are scarce. The higher VFA concentration in the rumen with barley than oats was in line with results of Harstadt and Nordheim (1996) and may be related to a higher starch content of barley than oats. Contrary to study of Harstadt and Nordheim (1996) no difference in rumen $\mathrm{pH}$ between barley and oats was found in the present study. Oats maintained higher rumen $\mathrm{pH}$ than barley in their study, where proportion of concentrate in the diet DM was over $60 \%$ as opposed to $40 \%$ in the present study. The slightly higher butyrate with barley in comparison to oats diets may be attributed to increases in the flow of protozoal $\mathrm{N}$ observed for barley-containing feeding (Ahvenjärvi et al. 2002). As there were no changes in relation to rumen $\mathrm{pH}$ between the barley and oats diets, reduced rumen and total tract digestibility of OM and NDF with oats reflects higher intake of fibre inherent to oats diets. This is consistent with lower $\mathrm{OM}$ and fibre digestibility of oats than barley as measured in a series of digestibility trials with sheep (Heikkilä et al. 1988). The tendency for higher rumen than total tract NDF digestion with barley in comparison to oats diets suggests that virtually all NDF digestion in barley diets occurred in the rumen. This is in agreement with the results obtained from barley diets using omasal sampling technique combined with a triple-marker method in nutrient flow measurements (Ahvenjärvi et al. 2002).

\section{$\mathrm{N}$ metabolism}

Grass-red clover vs. grass

The comparison of grass and red clover silage diets in terms of $\mathrm{N}$ metabolism is often confounded because of usually higher CP concentration and DM intake of the red clover diets. In the present study, silages made of pure grass or red-clover containing mixed sward with similar CP concentration and restricted rather than ad libitum feeding of cows were used. Thus, $\mathrm{N}$ intakes of grass (348 $\mathrm{g}$ $\left.\mathrm{d}^{-1}\right)$ and grass-red clover diets $\left(356 \mathrm{~g} \mathrm{~d}^{-1}\right)$ were almost equal. The greater non-ammonia $\mathrm{N}$ flow entering to the duodenum with grass-red clover than grass diets (365 vs. $317 \mathrm{~g} \mathrm{~d}^{-1}$ ) comprised of dietary $\mathrm{N}\left(+30 \mathrm{~g} \mathrm{~d}^{-1}\right)$ rather than microbial $\mathrm{N}\left(+18 \mathrm{~g} \mathrm{~d}^{-1}\right)$ reflecting as $7 \%$-units lowered feed $\mathrm{N}$ degradability in the rumen of cows fed grass-red clover diets.

The lower feed $\mathrm{N}$ degradability in red clover in comparison to grass silage in vivo (Dewhurst et al. 2003a) or other forage legumes in vitro (Broderick and Albrecht 1997) has been found earlier and attributed to the action of the polyphenol oxidase (PPO) enzyme in red clover reducing proteolysis (Jones et al. 1995). In a recent study, Sullivan and Hatfield (2006) demonstrated that combination of PPO and $o$-diphenol PPO substrates, both naturally present in red clover, is responsible for inhibiting postharvest proteolysis in red clover. It was 


\section{AGRICULTURAL AND FOOD SCIENCE}

Vanhatalo, A. et al. Responses of cows to grass-red clover diets

also shown that reduced proteolysis was possible to attain even with lower levels of PPO than typically found in red clover provided that $o$-diphenol was supplied, and that this system was sufficient to mediate proteolytic inhibition also in plant extracts normally lacking these components. In the present study, the proportion of red clover in the silage was $40 \%$ proposing that inhibition of proteolysis is effective even when plant material is harvested from mixed sward of grasses and red clover. This may be of interest because reduction of rumen $\mathrm{N}$ losses has been shown to have the greatest potential to improve $\mathrm{N}$ utilisation on grass silage based diets (Huhtanen and Shingfield 2005). Furthermore, unchanged total $\mathrm{N}$ digestibility between the silage diets suggests that inhibition of proteolysis in the rumen on grass-red clover diets did not impair post-ruminal $\mathrm{N}$ digestion in the present study.

The slightly higher microbial protein production in the rumen obtained with grass-red clover rather than grass silage diets may be explained for the most part with the lower ammonia and soluble $\mathrm{N}$ and higher residual WSC concentrations of grass-red clover than pure grass silage ( 94 vs. $59 \mathrm{~g}$ $\mathrm{kg}^{-1} \mathrm{DM}$ ) supplying amino acids and energy for rumen microbes. This together with slightly reduced OM digestion in the rumen resulted in a higher estimate of efficiency of microbial protein synthesis with grass-red clover diets. High residual sugar and low ammonia $\mathrm{N}$ concentrations in grass silage attained with a high application rate of formic acid has been shown to promote microbial production in the rumen (Jaakkola et al. 2006).

\section{Oats vs. barley}

Crude protein concentration of barley and oats may vary depending on agronomic practices such as use of $\mathrm{N}$ fertilisation level. In the present study, barley was higher in $\mathrm{CP}$ than oats resulting in a slightly higher CP intake with barley diets. However, the $\mathrm{N}$ digestion parameters such as non-ammonia $\mathrm{N}$ entering to the intestine between oats and barley diets were similar suggesting equal flow of amino acids (AA) to the small intestine for barley and oats. Numerically, in vivo rumen $\mathrm{N}$ degradability of barley diets was slightly higher than that of oats diets (0.69 vs. 0.66$)$ despite a much higher proportion of soluble $\mathrm{N}$ in oats rather than in barley N (Van Soest 1994). Slightly higher estimates for the efficiency of microbial protein synthesis with oats than barley diets were related to reduced ruminal OM digestibility of oats diets rather than for any particular improvement in microbial protein synthesis. The effects of the composition of energy supplements on microbial protein synthesis on grass silage based diets have generally been small as reviewed by Huhtanen (1998).

\section{Milk production}

Grass-red clover vs. grass

The milk yield of cows was rather low in the present study owing not only to the primiparous cows in mid-lactation but also to the lack of protein supplement in the concentrate supplement comprising solely of barley or oats. However, higher lactose, milk and ECM yields with grassred clover silages in comparison to pure grass silages are in good agreement with earlier results obtained from production trials (Heikkilä et al. 1992, 1996, Randby 1992, Tuori et al. 2000, Dewhurst et al. 2003b, Bertilsson and Murphy 2003). In these studies, the proportion of red clover in the silage varied in range of 0.26 to 0.70 and $\mathrm{OM}$ digestibility of the grass-red clover diet inconsistently from negative to positive in comparison to grass silage diets probably reflecting varying maturity stages of herbage at harvest between the trials. In the present study, higher milk yield was attained with silage containing $40 \%$ of red clover, and the $\mathrm{OM}$ digestibility of the grass-red clover and grass silage diets were similar. However, part of the increased production responses with red clover in the above mentioned production trials can be explained with consistently increased DM intake attributed to the ad libitum silage feeding. Present results with restricted feeding suggest that higher production responses to grass-red clover silages can not be explained solely by increased silage DM intakes but may also be associated with improved utilisation of feed nutrients.

In agreement with results of Randby (1992) and Dewhurst et al. (2003b) grass-red clover diet 
Vol. 15 (2006): 252-267.

did not affect milk fat or protein concentrations in the present study. In other studies, it has reduced milk fat (Heikkilä et al. 1992, Tuori et al. 2000, 2002) or protein contents (Heikkilä et al. 1992, Bertilsson and Murphy 2003). Contrasting results may be related to differences in supply of nutrients due to variation in silage DM intake and rumen fermentation in various experiments. The present results are consistent with unchanged DM intake and rumen fermentation pattern between the comparable silages. Due to higher milk yield grass-red clover diet increased yield of milk protein as found also in some production trials (Dewhurst et al. 2003b, Bertilsson and Murphy 2003). However, milk protein yield response of $35 \mathrm{~g} \mathrm{~d}^{-1}$ to higher post-ruminal non-ammonia $\mathrm{N}$ flows with grass-red clover diets calculated in terms of AA absorbed from the small intestine (MTT 2006) was only $20 \%$ compared with $51 \%$ or $61 \%$ observed for abomasally infused casein alone or together with glucose on grass silage based diets, respectively (Vanhatalo et al. 2003). This may imply that despite enhanced AA supply with grass-red clover relative to pure grass silage diets, further milk protein synthesis was still limited by inadequate supply of individual AA such as histidine or methionine identified as a first-limiting AA on grass silage based diets the ranking varying between the experiments as reviewed by Chamberlain and Yeo (2003). The low efficiency of use of additional AA for milk protein secretion may also be related to the use of plasma AA for hepatic glucose synthesis (Vanhatalo et al. 2003). The low proportion of propionate in the rumen VFA, and the increased milk lactose concentration with grass-red clover silage diets may support this view in the present study.

That CP intake was similar between the comparable silage diets $\mathrm{N}$ efficiency in terms of milk$\mathrm{N} /$ feed-N was slightly higher for grass-red clover than pure grass silage diets ( 27.2 vs. $26.3 \%)$. This is consistent with results of Dewhurst et al. (2003b) demonstrating that despite higher $\mathrm{CP}$ concentration of red clover than grass silage changing from grass silage to a mixture of grass silage and red clover in three separate comparisons increased milk protein yields and thus led only to a little, if any, further loss of $\mathrm{N}$ efficiency. The present re- sults support suggestion of Dewhurst et al. (2003b) of synergistic effect of the mixture of these forages on $\mathrm{N}$ efficiency. However, changing diet exclusively on red clover silage did not lead any further increases in milk protein yields but declined $\mathrm{N}$ efficiency markedly in these comparisons (Dewhurst et al. 2003b). Consistently with this finding higher post-ruminal AA flow with pure red clover silage diets relative to pure grass silage diets was not realised as increased milk protein yields in our recent study (Vanhatalo et al. unpublished results). Therefore, question arises whether combined PPO and $o$-diphenol system inherent to red clover (Sullivan and Hatfield 2006) may even impair efficiency of $\mathrm{N}$ utilisation on diets based exclusive use of red clover in dairy cow feeding. This question clearly merits further investigations.

\section{Oats vs. barley}

Consistently with earlier production trials (Moran 1986, Heikkilä et al. 1988, Martin and Thomas 1988, Ekern et al. 2003) oats increased lactose and milk yields and decreased milk protein content in comparison to barley in the present study. Decreased milk protein content with oats has been found repeatedly and as there were not any differences in the non-ammonia $\mathrm{N}$ flow to the lower tract between these diets it may reflect the dilution of protein into the greater amount of milk produced with oats. Oats has also often reduced milk fat content (Heikkilä et al. 1988, Martin and Thomas 1988, Ekern et al. 2003) but in the present study milk fat content was unchanged similarly to some other studies (Moran 1986, Tesfa et al. 1992). This was consistent with only minor changes between barley and oats in rumen fermentation pattern, the slightly lower butyrate with oats being in harmony with a slight numerical difference in milk fat content between oats and barley (44.4 vs. $\left.45.6 \mathrm{~g} \mathrm{~kg}^{-1}\right)$. Thus, the variation between the experiments in milk fat content may be explained with the variation in the forage:concentrate-ratio of the diets. Because the proportion of concentrate in the diet DM varied in range of $0.35-0.60$ in the above trials it is possible that with higher concentrate levels higher amounts of long-chain FA within oats have inhibited de novo milk fat synthesis. Owing to 


\section{AGRICULTURAL AND FOOD SCIENCE}

Vanhatalo, A. et al. Responses of cows to grass-red clover diets

variable effects on milk fat concentration oats in comparison to barley has either increased (Moran 1986, present study) or more often has had no effect on ECM yield (Heikkilä et al. 1988, Martin and Thomas 1988, Tesfa et al. 1992, Ekern et al. 2003). As there were less digestible OM available on oats than barley diets, additional lipids in oats diets, improved efficiency of feed nutrient utilisation (1.36 vs. $1.29 \mathrm{~kg} \mathrm{ECM} \mathrm{kg}^{-1}$ feed DM intake) or possibly increased use of body reserves may be associated with the higher ECM yield obtained for oats in the present study.

\section{Milk fat composition}

Using grass-red clover rather than pure grass silage diet had minor effects on milk FA composition with small increases in the proportions of C10:0 to C14:0, and C18:3. This was in line with the effects of 1:1 mixtures of grass and red clover silages in comparison to pure grass silages (Dewhurst et al. 2003b). Organoleptic quality of milk produced with red clover-containing silage was not much different from milk produced with pure grass silage. In the study of Bertilsson and Murphy (2003) the taste of milk containing red clover deviated more frequently from good quality milk than milk produced with perennial ryegrass.

In good agreement with other studies (Kankare and Antila 1984, Martin and Thomas 1988, Tesfa et al. 1992, Ekern et al. 2003) feeding oats in replacement for barley led to reductions in the contents of $\mathrm{C}_{10: 0}$ to $\mathrm{C}_{16: 0}$ and increases in the contents of $\mathrm{C}_{18: 0}$ and $\mathrm{C}_{18: 1}$ in total milk FA. Given that oats was $3 \%$-units higher in crude fat than barley cows received $170 \mathrm{~g} \mathrm{~d}^{-1}$ more fat with oats than barley diets. Fatty acid composition of the feeds was not determined in the present study but using literature values for barley and oats (Martin and Thomas 1988) it can be calculated that the oats diets provided approximately $100 \mathrm{~g} \mathrm{~d}^{-1}$ more of $\mathrm{C}_{18: 1}$ and 50 $\mathrm{g} \mathrm{d}^{-1}$ more of $\mathrm{C}_{18: 2}$ than the barley diets. This resulted in an increase of about $5 \%$-units of $\mathrm{C}_{18: 1}$ mainly at the expense of $\mathrm{C}_{16: 0}$ in total milk FA, changes that can be considered as beneficial for human health (Givens and Shingfield 2006). Re- spective changes obtained with oats were more notable, even twofold, when higher concentrate levels were used in other studies (Martin and Thomas 1988, Ekern et al. 2003) demonstrating that beneficial changes in milk FA composition, attributable to those obtained with rapeseed supplements in the diet (Givens and Shingfield 2006), can be obtained using oats rather than barley as grain supplement in dairy cow feeding. The results from the present and previous studies with oats represent low fat diets with fat concentration in the diet DM less than 5\%. Given the increasing interest for enhancing beneficial FA in milk fat, further studies of the effects of oats in other dietary conditions on milk FA composition including a detailed analysis of $\mathrm{C}_{18}$ isomers would be of particular interest.

\section{Conclusions}

Inclusion of red clover (40\% in the silage) or replacement of barley with oats at moderate level of concentrate supplementation (40\% of diet DM) had minor effects on rumen fermentation pattern on grass silage based diets. With equal DM and $\mathrm{N}$ intakes between comparable silage diets grass-red clover diet increased non-ammonia $\mathrm{N}$ flow entering to the small intestine. Increased $\mathrm{N}$ flow comprised of dietary rather than microbial $\mathrm{N}$ reflecting reduced $\mathrm{N}$ degradability in the rumen of cows fed grass-red clover diets. Because this was associated with increased protein yield and slightly increased efficiency of conversion of feed $\mathrm{N}$ into milk $\mathrm{N}$ it is suggested that silage prepared from mixed grassred clover sward may have positive synergistic effect on $\mathrm{N}$ efficiency. However, efficiency of use of nutrients was presumably limited by inadequate supply of amino acids and/or glucose also on grass-red clover silage based diets. Feeding oats in replacement for barley reduced OM and fibre digestibility reflecting higher intake of fibre inherent to oats diets but did not affect post-ruminal $\mathrm{N}$ flow. Because inclusion of red clover and replacement of barley with oats in grass silage based diets pro- 
Vol. 15 (2006): 252-267.

moted milk and ECM yields use of grass-red clover mixtures and oats could be favoured in dairy cow rations. This is further supported with increases in beneficial FA in milk fat attributable especially to use of oats in dairy cow feeding.

Acknowledgements. The skilled technical assistance and care of the experimental animals by Aino Matilainen and her staff, and Laboratory staff of Animal Nutrition, MTT Agrifood Research Finland are gratefully acknowledged.

\section{References}

Ahvenjärvi, S., Vanhatalo, A. \& Huhtanen, P. \& Varvikko, T. 1999. Effects of supplementation of a grass silage and barley diet with urea, rapeseed meal and heat-moisture-treated rapeseed cake on omasal digesta flow and milk production in lactating dairy cows. Acta Agriculturae Scandinavica, Section A. Animal Science 49: 179189.

Ahvenjärvi, S., Vanhatalo, A. \& Huhtanen, P. 2002. Supplementing barley or rapeseed meal to dairy cows fed grass-red clover silage: 1 . Rumen degradability and microbial flow. Journal of Animal Science 80: 21762187.

Bertilsson, J. \& Murphy, M. 2003. Effects of feeding clover silages on feed intake, milk production and digestion in dairy cows. Grass and Forage Science 58: 309-322.

Brandt, M. \& Allam, S.M. 1987. Analytik von $\mathrm{TiO}_{2}$ im Darminhalt und Kotnach Kjeldahl-aufschluß. Archiv Tierernährung 37, 5: 453-454.

Broderick, G.A. \& Albrecht, K.A. 1997. Ruminal in vitro degradation of protein in tannin-free and tannin-containing forage legume species. Crop Science 37: 1884-1891.

Chamberlain, D.G. \& Yeo, J.-M. 2003. Effects of amino acids on milk production. In: D'Mello, J.P.F. (ed.). Amino acids in animal nutrition. Guildford and King's Lynn: Biddles Ltd. p. 369-387.

Dewhurst, R.J., Evans, R.T., Scollan, N.D., Moorby, J.M., Merry, R.J. \& Wilkins R.J. 2003a. Comparison of grass and legume silages for milk production. 2. In vivo and in sacco evaluations of rumen function. Journal of Dairy Science 86: 2612-2621.

Dewhurst, R.J., Fisher, W.J., Tweed, J.K.S. \& Wilkins R. J. 2003b. Comparison of grass and legume silages for milk production. 1. Production response with different levels of concentrate. Journal of Dairy Science 86: 2598-2611.

Ekern, A., Havrevoll, Ø., Haug, A., Berg, J. Lindstad, P. \& Skeie, S. 2003. Oat and barley based concentrate supplements for dairy cows. Acta Agriculturae Scandinavica, Section A, Animal Science 53: 65-73.

Faichney, G.H. 1975. The use of markers in partitioning digestion within gastrointestinal tract of ruminants. In:
McDonald, I.W. \& Warner, A.C.I. (eds.). Digestion and metabolism of in the ruminant. Sydney, Australia: The University of New England Publishing Unit. p. 277291.

Givens, D.I. \& Shingfield, K.J. 2006. Optimising dairy milk fatty acid composition. In: Williams, C. \& Buttriss, J. (eds.). Improving the fat contents of food. UK, Cambridge: Woodhead Publishing Limited. p. 252-280.

Harstad, O.M. \& Nordheim, H. 1996. Virkning av karbohydratkilde i kraftfôret på miljøet i vomma hos mjølkeku. In: Husdyrforsøksmøtet, 14-15 February 1996. Department of Animal Science, Agricultural University of Norway. p. 144-148.

Hart, F.J. \& Leibholz, J. 1990. A note on the flow of endogenous protein to the omasum and abomasum of steers. Animal Production 51:217-219.

Heikkilä, T., Toivonen, V. \& Mela, T. 1992. Comparison of red clover-grass silage with grass silage for milk production. In: Proceedings of the 14th General Meeting of the European Grassland Federation. Lahti: Markprint Oy. p. 388-391.

Heikkilä, T., Toivonen, V. \& Mela, T. 1996. Effects of red clover-grass, grass and annual ryegrass silages with two concentrate protein levels on milk production. In: Parente, G. et al. (eds.). Grassland and land use systems. Proceedings of the 16th General Meeting of the European Grassland Federation. Gorizia: Organizing Committee of the 16th General Meeting of the European Grassland Federation. p. 447-450.

Heikkilä, T., Väätäinen, H. \& Lampila, M. 1988. Barley or oats for dairy cows? Proceedings VI World Conference on Animal Production, Helsinki 1988, Jyväskylä: Gummerus Oy Kirjapaino. p. 336.

Huhtanen, P. 1998. Supply of nutrients and productive responses in dairy cows given diets based on restrictively fermented silage. Agricultural and Food Science in Finland 7: 219-250.

Huhtanen, P. \& Heikkilä, T. 1996. Effects of physical treatment of barley and rapeseed meal in dairy cows given grass silage-based diets. Agricultural and Food Science in Finland 5: 399-412.

Huhtanen, P. \& Shingfield, K.J. 2005. Grass silage: factors affecting efficiency of $\mathrm{N}$ utilisation in milk production. In: Park, R.S. \& Stronge, M.D. (eds.). Silage production and utilisation. Proceedings of the 14th international silage conference, a satellite workshop of the 20th international grassland congress, in July in Belfast, Northern Ireland. Wageningen: Wageningen Academic Publishers. p. 35-50.

Jaakkola, S., Kaunisto, V. \& Huhtanen, P. 2006. Volatile fatty acid proportions and microbial protein synthesis in the rumen of cattle receiving grass silage ensiled with different rates of formic acid. Grass and Forage Science 61: 282-292.

Jones, B.A., Muck, R.E. \& Hatfield, R.D. 1995. Red clover extracts inhibit legume proteolysis. Journal of Science of Food and Agriculture 67: 329-333.

Kankare, V. \& Antila, V. 1984. The effect of feed grains on the fatty acid composition of milk fat. Journal of Agricultural Science in Finland 56: 33-38.

Kuoppala, K., Ahvenjärvi, S., Rinne, M. \& Vanhatalo, A. 2005. NDF digestion in dairy cows fed grass or red clo- 


\section{AGRICULTURAL AND FOOD SCIENCE}

Vanhatalo, A. et al. Responses of cows to grass-red clover diets

ver silages cut at two stages of growth. In: Park, R.S. \& Stronge, M.D. (eds.). Silage production and utilisation. Proceedings of the 14th international silage conference, a satellite workshop of the 20th international grassland congress, in July in Belfast, Northern Ireland. Wageningen: Wageningen Academic Publishers. p. 164.

McAllan, A.B. \& Smith, R.H. 1983. Factors influencing the digestion of dietary carbohydrates beween the mouth and abomasum of steers. British Journal of Nutrition 50: 445-454.

McDonald, P., Henderson, A.R. \& Heron, S.J.E. 1991. The biochemistry of silage. 2nd ed. Aberystwyth: Cambrian printers, UK. 340 p.

Martin, P.A. \& Thomas, P.C. 1988. Dietary manipulation of the yield and composition of milk: Effects of dietary inclusion of barley and oats in untreated or formaldehyde treated forms on milk fatty acid composition. Journal of the Science of Food and Agriculture 43: 145-154.

Moran, J.B. 1986. Cereal grains in complete diets for dairy cows: A comparison of rolled barley, wheat and oats and of three methods of processing oats. Animal Production 43: 27-36.

Mould, F.L. \& Ørskov, E.R. 1983. Manipulation of rumen fluid $\mathrm{pH}$ and its influence on cellulolysis in sacco, dry matter degradation and the rumen microflora of sheep offered either hay or concentrate. Animal Feed Science and Technology 10: 1-14.

MTT 2006. Rehutaulukot ja ruokintasuositukset (Feed tables and feeding recommendations). Jokioinen: MTT Agrifood Research Finland. Updated 14 Feb 2006. Cited 8 June 2006. Available on the Internet: http://www. agronet.fi/rehutaulukot/. URN:NBN:fi-fe20041449.

Randby, Å.T. 1992. Grass-clover silage for dairy cows. In: Proceedings of the 14th General Meeting of the European Grassland Federation. Lahti: Markprint Oy. p. 272-275.

Rinne, M. 2000. Influence of the timing of the harvest of primary grass growth on herbage quality and subsequent digestion and performance in the ruminant animal. University of Helsinki, Department of Animal Science. Publications 54. 42 p. +5 encl. Academic dissertation. Available on the Internet: http://ethesis.helsinki. fi/julkaisut/maa/kotie/vk/rinne.

Schwab, C.G., Huhtanen, P., Hunt, C.W. \& Hvelplund, T. 2005. Nitrogen requirements of cattle. In: Pfeffer, E. \& Hristov, A. (eds.). Nitrogen and phosphorus nutrition of cattle. Reducing the environmental impact of cattle operations. UK, King's Lynn: Biddles Ltd. p. 13-70.

Snedecor, G.W. \& Cochran, W.G. 1967. Statistical methods. 6th edition. USA, Ames, lowa: The lowa State University Press. 593 p.

Sullivan, M.L. \& Hatfield, R.D. 2006. Polyphenol oxidase and 0 -Diphenols inhibit postharvest proteolysis in red clover and alfalfa. Crop Science 46: 662-670.

Tesfa, A.T., Tuori, M., Syrjälä-Qvist, L. \& Kaustell, K.1992. Effects of partial replacement of barley with rapeseed oil or birch wood in comparison to barley and oats on the performance and blood metabolites of lactating cows. Agricultural Science in Finland 1: 255-265.

Thomas, C., Aston, K. \& Daley, S.R. 1985. Milk production from silage 3. A comparison of red clover with grass silage. Animal Production 41: 23-31.

Tuori, M., Syrjälä-Qvist, L., Bertilsson, J. \& Wilkins, R. 2000. Milk production based on leguminous silage: Red clover and fodder galega in Finland. In: Søegaard, K. et al. (eds.). Grassland farming: Balancing environmental and economic demands. Proceedings 18th General Meeting of the European Grassland Federation. Grassland in Europe, vol. 5: 356-358.

Tuori, M., Syrjälä-Qvist, L. \& Jansson, S. 2002. Red clover and meadow fescue silages fed in different proportions in milk production. In: Proceedings of the 13th International silage conference, 11-13 September 2002, Auchincruive, Scotland. p. 130-131.

Uden, P., Colucci, P.E. \& Van Soest, P.J. 1980. Investigation of chromium, cerium and cobalt as markes in digesta. Rate of passage studies. Journal of the Science of Food and Agriculture 3: 625-632.

Vanhatalo, A., Heikkilä, T. \& Gäddnäs, T. 1995. Microbial protein synthesis in dairy cows fed grass silage or red clover-grass silage. In: Proceedings of the 7th International Symposium of Protein Metabolism and Nutrition. EAAP Publication no. 81. p. 275.

Vanhatalo, A., Varvikko, T. \& Aronen, I. 1992. The effect of type of additive on rumen fermentation and digestion of grass silage in cattle. Agricultural Science in Finland 1: 163-175.

Vanhatalo, A., Varvikko, T. \& Huhtanen, P. 2003. Effects of casein and glucose on responses of cows fed diets based on restrictively fermented grass silage. Journal of Dairy Science 86: 3260-3270.

Van Soest, P.J. 1994. Nutritional ecology of the ruminant. 2nd ed. Ithaca: Cornell University Press. $476 \mathrm{p}$. 


\title{
SELOSTUS
}

\section{Säilörehu- ja viljaväkirehutyypin vaikutus pötsikäymiseen, ravintoaineiden virtaukseen ja sulatukseen sekä maidontuotantoon}

\author{
Aila Vanhatalo, Tomas Gäddnäs ja Terttu Heikkilä \\ Helsingin yliopisto ja Maa- ja elintarviketalouden tutkimuskeskus
}

Tutkimuksessa selvitettiin heinäkasvisäilörehun ja punaapilapitoisen heinäkasvisäilörehun sekä ohran ja kauran vaikutusta pötsikäymiseen, ravintoaineiden virtaukseen ja sulatukseen sekä maitotuotokseen ja maidon koostumukseen.

Säilörehut tehtiin nurminata-timotein ja puna-apilapitoisen $(40 \%)$ nurminata-timotein toisesta sadosta, joita lannoitettiin $90 \mathrm{~kg} \mathrm{~N} \mathrm{ha}^{-1}$ heinäkasvi- ja $50 \mathrm{~kg} \mathrm{~N} \mathrm{ha}^{-1}$ apilapitoiselle nurmelle. Rehut korjattiin kelasilppurilla ja säilöttiin AIV 2-happosäilöntäaineella (5,0 ja 5,6 l/t) torneihin. Koe toteutettiin neljällä pötsi- ja ohutsuolifistelöidyllä ayrshire-ensikolla $4 \times 4$ latinalaisena neliönä, jossa koeruokinnat olivat $2 \times 2$ faktoriaalisesti järjestetyt säilörehun ja väkirehun suhteen. Koejakson pituus oli 28 päivää. Lehmät ruokittiin yksilöllisesti tuotoksen mukaan siten, että ruokintataso ja ruokinnan karkearehuväkirehusuhde (60:40) pysyivät samana koko kokeen ajan. Ohra ja kaura olivat yksinomaisena väkirehuna. Ravintoaineiden virtaus ohutsuoleen, ruokintojen sulavuus ja mikrobisynteesi määritettiin merkkiainemenetelmällä.

Molemmat säilörehut olivat hyvälaatuisia. Raakavalkuaispitoisuus oli sama (160 vs. $159 \mathrm{~g} / \mathrm{kg} \mathrm{ka}$ ), mutta puna-apilapitoisen säilörehun valkuainen oli hajonnut vähemmän ja sokeria oli enemmän kuin heinäkasvisäilörehussa. Pötsikäymisessä muodostuneiden rasvahappojen suhteissa ja rehuannoksen sulavuudessa ei ollut eroa säilörehujen välillä. Sen sijaan ei-ammoniakkitypen virtaus ohutsuoleen lisääntyi puna-apilapitoista säilörehua syötettäessä pelkkään heinäkasvisäilörehuun verrattuna. Tämä johtui lisääntyneestä mikrobitypen ja erityisesti rehuperäisen typen virtauksesta ohutsuoleen. Näin ollen rehutypen in vivo -pötsihajoavuus oli merkitsevästi pienempi apilapitoista säilörehua syötettäessä. Typen saanti oli kuitenkin lähes sama molemmilla ruokinnoilla, eikä typen kokonaissulavuudessa ollut eroa säilörehujen välillä. Lehmät myös tuottivat puna-apilapitoisella säilörehulla enemmän maitoa $(1,2 \mathrm{~kg} / \mathrm{d})$, energiakorjattua maitoa, valkuaista ja laktoosia. Maidon rasva-, valkuais- ja ureapitoisuudessa tai maitorasvan koostumuksessa ei ollut merkittäviä eroja säilörehujen välillä. Rehutypen hyväksikäyttö maitovalkuaiseksi oli hieman parempi puna-apilapitoista säilörehua syötettäessä verrattuna heinäkasvisäilörehuun. Säilörehujen ja viljaväkirehujen välillä ei ollut merkitsevää yhdysvaikutusta missään mitatussa tutkitussa muuttujassa.

Kaura- ja ohraruokinnan välillä oli vain pieniä eroja pötsikäymisessä ja ei-ammoniakkitypen virtauksessa ohutsuoleen, mutta kauraruokinta huononsi rehuannoksen orgaanisen aineen ja kuidun sulavuutta. Kauraruokinnalla lehmät kuitenkin tuottivat enemmän maitoa $(1.1 \mathrm{~kg} / \mathrm{d})$, energiakorjattua maitoa ja laktoosia kuin ohraruokinnalla, mutta maidon valkuaispitoisuus oli pienempi. Rehutypen hyväksikäyttö maitovalkuaiseksi oli myös hieman parempi kaura- kuin ohraruokinnalla. Lisäksi kaura lisäsi $\mathrm{C}_{18: 0}$ ja $\mathrm{C}_{18: 1}$ rasvahappojen osuutta maitorasvassa ja vähensi $\mathrm{C}_{10: 0}-\mathrm{C}_{16: 0}$ osuutta verrattuna ohraan. Puna-apilapitoisen säilörehun ja kauran edulliset vaikutukset ravintoaineiden hyväksikäytössä, maitotuotoksessa ja maitorasvan koostumuksessa puoltavat niiden käytön lisäämistä lypsylehmien rehuannoksissa. 